\title{
Plant-microbe Interactions in Rhizospheric Soil Treated with Different Quality Organic Residues
}

\author{
Saowalak Somboon ${ }^{1}$ (D) Bhanudacha Kamolmanit ${ }^{2}$ id and Phrueksa Lawongsa ${ }^{1 *}$ (D) \\ ${ }^{1}$ Department of Soil Science and Environment, Faculty of Agriculture, Khon Kaen University, \\ Khon Kaen, Thailand. \\ ${ }^{2}$ Course of Agriculture, Faculty of Science and Technology, Nakhon Ratchasima Rajabhat University, Nakhon \\ Ratchasima, Thailand.
}

\begin{abstract}
The objective of this research was to study plant-microbe interactions in rhizospheric soil treated with different quality organic residues in short-term incubation of the soil and subsequent planting of maize crop. The treatments combinations were, 1) untreated soil (control; CT), 2) groundnut stover (GN) with high nitrogen (N) but low lignin (L) and polyphenol (PP), 3) tamarind leaf and petiole litter (TM) with medium $N, L$ and $P P, 4$ ) rice straw (RS) with low $N$, $L$ and PP but high cellulose, 5) GN+TM, 6) GN+RS and 7) TM+RS. Single and mixed residue additions of GN and TM, both high and intermediate quality, resulted in higher soil microbial properties and nutrients than the application of RS as a low quality. Accordingly, the application of the former group increased microbial abundances (i.e., bacteria, archaea, and fungi), elevated the enzymes related to the decomposition of organic residue (i.e., invertase, protease, phenoloxidase and peroxidase activity), and enhanced soil nutrients and plant growth. The results indicated that the chemical compositions (N, L, and PP) of the organic residues amendment are key factors regulating soil microbial abundance and enzyme activity both in after incorporation and after planting. Moreover, bacterial and archaeal abundance, and microbial activities including soil respiration, invertase, protease, and peroxidase activity in the soil after planting higher than those in the soil before planting.
\end{abstract}

Keywords: Rhizospheric microorganisms, Litter quality, Enzyme activity, Soil nutrient

\footnotetext{
*Correspondence: phrula@kku.ac.th; +66-43-364639

(Received: July 16, 2021; accepted: September 29, 2021)

Citation: Somboon S, Kamolmanit B, Lawongsa P. Plant-microbe Interactions in Rhizospheric Soil Treated with Different Quality Organic Residues. J Pure Appl Microbiol. 2021;15(4):1915-1930. doi: 10.22207/JPAM.15.4.13

(C) The Author(s) 2021. Open Access. This article is distributed under the terms of the Creative Commons Attribution 4.0 International License which permits unrestricted use, sharing, distribution, and reproduction in any medium, provided you give appropriate credit to the original author(s) and the source, provide a link to the Creative Commons license, and indicate if changes were made.
} 


\section{INTRODUCTION}

Crop residue is a significant organic matter, returning nutrient recycling to the soil and improving physical, chemical and biological soil properties. ${ }^{1}$ Consequently, it creates a relatively favorable environment for plant growth. However, the incorporation of crop residues impacts the soil environment and the microbial population and activity in the soil, leading to nutrient transformations. ${ }^{2}$

Tropical sandy soils have low soil organic carbon (SOC), a low cation exchange capacity (CEC), and a high risk of nutrient leaching. ${ }^{3}$ Therefore, the input of appropriate quality organic residues is an ultimately management option to improve and maintain physical and chemical soil fertility to sustain its production. ${ }^{4}$ Moreover, the application of organic residues with different qualities resulted in differences in plant growth parameters. For example, applying nitrogen-rich legume residues such as groundnut with and without chemical fertilizer resulted in the incredible growth of maize due to the high nitrogen (N) and phosphorus (P) uptakes. ${ }^{5}$ Therefore, more scientific shreds of evidence on the mechanisms involved in soil microorganisms are required to manage soil and sustain crop productivity effectively.

Soil microorganisms play essential roles in the decomposing organic residues and nutrient cycles. ${ }^{6,7}$ Plant growth and productivity are related to the interactions between plant roots and the microbial populations within the soils containing various microbial properties to decompose the organic carbon fraction like cellulose, lignin, hemicelluloses, chitin, and lipids in soil organic matter. ${ }^{8,9}$ Previous studies used organic inputs at low $\mathrm{N}$ but high in lignin and polyphenol contents such as dipterocarp leaves. As a result, it depressed fungal abundance but promoted specialized decomposers (e.g., Aspergillus fumigatus and Anguillospora longissimi) with increased polyphenoloxidase activity. The degree of functional redundancy for invertase and B-glucosidase activities induced after adding simply decomposable rice straw and groundnut stover. In contrast, higher nitrogen availability in the tamarind treatment increased fungal abundance (i.e., Fusarium oxysporum, Myceliopthora thermophila, and Aspergillus versicolor) and promoted invertase and B-glucosidase activities, whereas peroxidase activity was suppressed. ${ }^{10}$ Therefore, the effects of biochemically contrasting organic residues on bacterial and archaea decomposers in tropical sandy soil are required for further research to yield scientific evidence on this relevance.

Although plant-microbe interactions in soil treated with organic residues have been reported, comparing the organic residues with biochemically contrasting qualities in a tropical sandy soil are little known. Therefore, the research project hypothesized that (i) whether soil microbial abundance and activity, soil nutrients content and plant growth were higher in soil treated with high and intermediate quality organic residues than in soil treated with low quality organic residue and (ii) whether microbial abundance and activity were higher in rhizospheric soil (after planting) than in soil before planting.

In our study, three organic residues were selected, including groundnut stover (high quality), tamarind (intermediate quality) and rice straw (low quality), and they were incorporated into the soil as single treatments or in combinations with other residues to improve decomposition and nutrient release. According to Partey et al., mixing high quality organic residue (Tithonia diversifolia, Vicia faba) with low-quality organic residue (Zea mays) improved the mixture's $\mathrm{N}$ composition and $\mathrm{C}: \mathrm{N}$ ratio, leading to enhance decomposition and nutrient release of low quality residues. ${ }^{11}$ Moreover, mixing low quality and high quality organic inputs equally resulted in a mineralization pattern and the weighted average patterns of two separate materials. ${ }^{12}$ Kaewpradit et al. showed that mixing groundnut residues with rice straw led to microbial $\mathrm{N}$ immobilization/remobilization and could delay $\mathrm{N}$ release during the lag period. ${ }^{13}$ This research aimed to study plant-microbe interactions in rhizospheric soil treated with different quality organic residues in short-term soil incubation and investigate its utilization in the planting of maize crops.

\section{MATERIALS AND METHODS}

Soil

The soil used in the experiment was collected from a field at the research station of the Agriculture and Co-operatives of the Northeast at Tha Phra subdistrict, Khon Kaen province, Thailand 
$\left(16^{\circ} 20^{\prime} \mathrm{N} ; 102^{\circ} 49^{\prime} \mathrm{E}\right)$ at $0-15 \mathrm{~cm}$ depth. The soil textural class is loamy sand $(85.4 \%$ sand, $10.0 \%$ silt and $4.6 \%$ clay). The soil was air-dried under the shade and sieved to pass through a $2 \mathrm{~mm}$. Details of initial soil properties are given in Table 1.

\section{Experimental design and treatments}

A short-term pot experiment was carried out from April to July in 2018 in the greenhouse at Khon Kaen University, Khon Kaen province, Thailand. Groundnut (Arachis hypogaea) stover, tamarind (Tamarindus indica) leaf and rice straw (Oryza sativa) were used as raw organic residues in the investigation, and their chemical compositions were shown in Table 2. Organic residues were air-dried and cut into pieces of 5-10 $\mathrm{cm}$ size (groundnut stover and rice straw), whereas tamarind was applied as whole leaves plus cut petioles $(1-3 \mathrm{~cm})$. Technically, seven treatments were assigned in a randomized complete block design (RCBD) with three replications. They are 1) untreated soil as control (CT), 2) groundnut stover (GN) as a high quality soil, 3) tamarind leaf (TM) as an intermediate quality soil, 4) rice straw (RS) as a low quality soil, 5) GN+TM, 6) GN+RS, and 7) TM+RS.

\section{Greenhouse experiment}

Dry soil was sieved through a $2 \mathrm{~mm}$ screen and the soil of $6 \mathrm{~kg}$ was loaded into each pot with a diameter of $26 \mathrm{~cm}$ and height of $26 \mathrm{~cm}$. Before loading of the soil, the soil was mixed with the organic residues at the rate of $10 \mathrm{t} \mathrm{ha}^{-1}$ for single treatments and 5:5 $\mathrm{t} \mathrm{ha}^{-1}$ for each organic residue for combination treatments. The treatments were then incorporated for 28 days.

The $F_{1}$ hybrid (Pacific 339) of maize (Zea mays Linn) was planted into the pots for 56 days (vegetative stage) by direct seeding. The seedling

Table 1. Soil physical and chemical properties used in the experiment before incorporation of organic matter

\begin{tabular}{lc}
\hline \multicolumn{2}{c}{ Soil properties } \\
\hline Soil bulk density $\left(\mathrm{g} \mathrm{cm}^{-3}\right)$ & 1.43 \\
Soil moisture (\%) & 1.01 \\
Soil pH & 6.13 \\
Soil electrical conductivity (dS m$\left.)^{-1}\right)$ & 0.051 \\
Soil organic carbon (\%) & 0.32 \\
Soil organic matter $(\%)$ & 0.55 \\
Total $\mathrm{N}(\%)$ & 0.028 \\
Ammonium $\left(\mathrm{NH}_{4}^{+}\right)\left(\mathrm{mg} \mathrm{kg}^{-1}\right)$ & 12.35 \\
Nitrate $\left(\mathrm{NO}_{3}^{-}\right)\left(\mathrm{mg} \mathrm{kg}^{-1}\right)$ & 0.31 \\
Available $\mathrm{P}\left(\mathrm{mg} \mathrm{kg}^{-1}\right)$ & 4.82 \\
Extractable $\mathrm{K}\left(\mathrm{mg} \mathrm{kg}^{-1}\right)$ & 31.63 \\
Extractable Ca $\left(\mathrm{mg} \mathrm{kg}^{-1}\right)$ & 57.78 \\
Extractable $\mathrm{Mg}\left(\mathrm{mg} \mathrm{kg}^{-1}\right)$ & 8.68 \\
Soil cation exchange capacity & 2.51 \\
(cmol kg-1) & \\
\hline
\end{tabular}

Table 2. Chemical compositions of organic residues used in the experiment

\begin{tabular}{lccc}
\hline Chemical composition & \multicolumn{3}{c}{ Organic residues } \\
\cline { 2 - 4 } & $\begin{array}{c}\text { Groundnut } \\
\text { stover }\end{array}$ & $\begin{array}{c}\text { Tamarind } \\
\text { leaf }\end{array}$ & $\begin{array}{c}\text { Rice } \\
\text { straw }\end{array}$ \\
\hline Carbon (C) $\left(\mathrm{g} \mathrm{kg}^{-1}\right)$ & 396 & 424 & 348 \\
Nitrogen (N) $\left(\mathrm{g} \mathrm{kg}^{-1}\right)$ & 20.9 & 11.9 & 4.9 \\
Cellulose $(\mathrm{CL})\left(\mathrm{g} \mathrm{kg}^{-1}\right)$ & 303.8 & 237.0 & 476.8 \\
Lignin (L) $\left(\mathrm{g} \mathrm{kg}^{-1}\right)$ & 69.2 & 161.2 & 26.4 \\
Polyphenol (PP) $\left(\mathrm{g} \mathrm{kg}^{-1}\right)$ & 12.3 & 38.8 & 8.3 \\
C/N ratio & 19.2 & 35.4 & 78.5 \\
L/N ratio & 3.4 & 14.1 & 5.4 \\
L/CL ratio & 0.3 & 0.7 & 0.1 \\
PP/N ratio & 0.6 & 3.4 & 1.7 \\
(L+PP)/N ratio & 4.0 & 17.5 & 7.2 \\
Cations (g kg-1) & & & \\
Potassium (K) & 25.10 & 6.24 & 14.40 \\
Calcium (Ca) & 21.10 & 35.00 & 4.21 \\
Magnesium (Mg) & 6.05 & 4.53 & 1.29 \\
Quality & High & Intermediate & Low \\
\hline
\end{tabular}

Source: Modified from Xayavong. ${ }^{5}$ 
was thinned to one plant per pot at 10 days after planting (DAP). The treatments were assigned in a randomized complete block design with three replications.

Water was supplied to the experiment at $70 \%$ of water holding capacity, which was calculated at $12.37 \%$ by weight. Fertilizers as $\mathrm{NH}_{4} \mathrm{NO}_{3}, \mathrm{Ca}\left(\mathrm{H}_{2} \mathrm{PO}_{4}\right) 2 . \mathrm{H}_{2} \mathrm{O}$ and $\mathrm{KCl}$ were applied to the crop at the rates of 70.30,30.70, $58.35 \mathrm{~kg} \mathrm{ha}^{-1}$, respectively at two splits at 1 and 25 DAP. ${ }^{5}$ Manual weed control was controlled regularly.

\section{Soil and plant analysis}

For soil chemical analysis, soil samples were taken at the initiation of the experiment, 28 days after incorporation (DAI) and 56 DAP of maize. Soil $\mathrm{pH}$ was determined in a 1:2.5 soil:distilled water ratio using $\mathrm{pH}$ meter. Electrical conductivity (EC) was determined in a 1:5 soil:distilled water ratio using EC meter.

The soil was analyzed for soil organic matter (SOM) and soil organic carbon (SOC) using wet oxidation method described by Walkley and Black method. OM content in soil was calculated using the following equation, assuming that $\mathrm{OC}$ content of SOM is $58 \%{ }^{14}$ :

$\mathrm{OM}=\% \mathrm{OC} \times 1.724$

Total nitrogen $(\mathrm{N})$ content in soil was determined using Kjeldahl method as described by Bremner. ${ }^{15}$ Ammonium $\left(\mathrm{NH}_{4}{ }^{+}\right)$content in soil was extracted by $2 \mathrm{M} \mathrm{KCl}$ and using salicylate-hypochlorite colorimetric method, ${ }^{16}$ while nitrate $\left(\mathrm{NO}_{3}{ }^{-}\right)$content in soil was extracted by $0.5 \mathrm{M}$ potassium sulfate and using salicylic acid colorimetric method. ${ }^{17}$ Available phosphorus content in soil was determined according to Bray II method described by Bray and Kurtz. ${ }^{18}$

Extractable potassium (K), extractable calcium (Ca) and extractable magnesium ( $\mathrm{Mg}$ ) content in soil were extracted with $25 \mathrm{ml}$ of 1 $\mathrm{N}$ ammonium acetate at $\mathrm{pH} 7.0$ and analysis of extract by atomic absorption spectrophotometer. ${ }^{19}$ Soil cation exchange capacity (CEC) was measured by extracting soil with $1 \mathrm{~N}$ ammonium acetate at $\mathrm{pH} 7.0 .^{20}$

Soil samples were taken at three stages including at the initiation of the experiment,

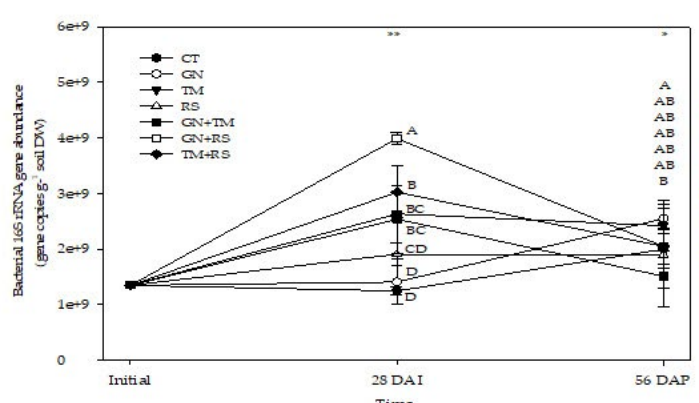

(a)

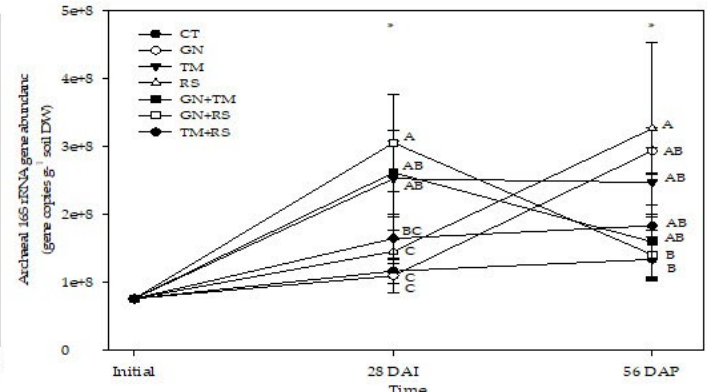

(b)

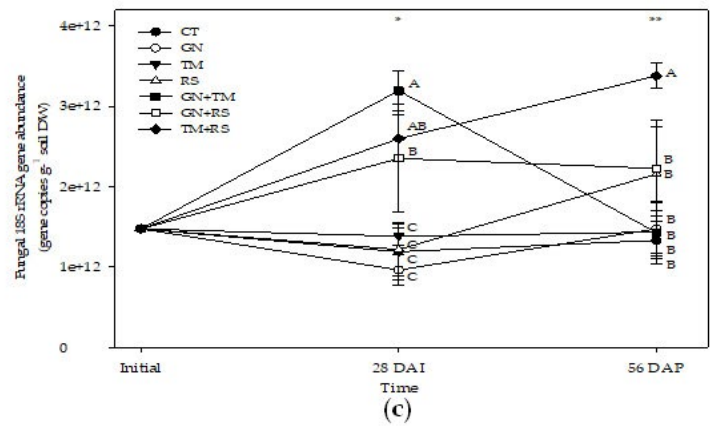

Fig. 1. Bacterial (a), archaeal (b), and fugal (c) abundance in soil treated with different quality organic (CT: untreated control, GN: groundnut, TM: tamarind, RS: rice straw, GN+TM: groundnut + tamarind, GN+RS: groundnut + rice straw, TM+RS: tamarind + rice straw). ${ }^{*}, * *$ significantly different at $p<0.05$, and 0.01 , respectively. 
after incorporation at 7, 14, 21 and 28 days and after planting at 7, 14, 21, 28, 35, 42, 49 and 56 days. The soil samples were taken near root zone (rhizosphere) and the samples were analyzed for microbial abundances using realtime polymerase chain reaction (PCR). The soil samples were also analyzed for gene density of 16 $S$ rRNA of bacteria using forward primer Eub338 (5'-ACTCCTACGGGAGGCAGCAG) ${ }^{21}$ and reverse primer Eub518 (5'-ATTACCGCGGCTGCTGG), ${ }^{22}$ the density of $18 \mathrm{~S}$ rRNA of fungi using forward primer FF390 (5'-CGATAACGAACGAGACCT and reverse primer FR1 (5'-AICCATTCAATCGGTAITCATTCA ${ }^{23}$ and density of $16 \mathrm{~S}$ rRNA of archaea using forward primer Ar109f (5'-ACKGCTCAGTAACACGT) and reverse primer Ar912r (5'- CTCCCCCGCCAATTCCTTTA). ${ }^{24}$

Soil respiration was determined by measuring carbon dioxide $\left(\mathrm{CO}_{2}\right)$ released from

Table 3. Chemical properties of the soils at initial stage, 28 days of incubation and 56 days after planting of maize

\begin{tabular}{|c|c|c|c|c|c|c|c|c|}
\hline \multirow{2}{*}{$\begin{array}{l}\text { Chemical } \\
\text { properties }\end{array}$} & \multirow[t]{2}{*}{ Time } & \multicolumn{6}{|c|}{ Treatment } & \multirow[b]{2}{*}{$\mathrm{TM}+\mathrm{RS}$} \\
\hline & & $\mathrm{CT}$ & GN & TM & RS & $\mathrm{GN}+\mathrm{TM}$ & $\mathrm{GN}+\mathrm{RS}$ & \\
\hline \multirow[t]{3}{*}{$\mathrm{pH}$} & Initial & 6.13 & $6.13 C$ & $6.13 C$ & $6.13 \mathrm{~B}$ & $6.13 C$ & $6.13 C$ & $6.13 C$ \\
\hline & 28DAI & $6.14 d$ & $7.20 \mathrm{Aa}$ & 7.10Aabc & 7.08Aabc & 7.17Aab & $7.05 \mathrm{Abc}$ & $6.99 A C$ \\
\hline & 56DAP & $6.22 d$ & $6.68 \mathrm{Bbc}$ & 7.00Ba & $6.55 \mathrm{ABbc}$ & $6.90 \mathrm{Ba}$ & $6.72 \mathrm{Ba}$ & 6.68Ba \\
\hline SOM & Initial & $0.55 \mathrm{~A}$ & 0.55 & 0.55 & 0.55 & 0.55 & 0.55 & 0.55 \\
\hline \multirow[t]{2}{*}{ (\%) } & 28DAI & $0.43 B$ & 0.52 & 0.53 & 0.53 & 0.52 & 0.55 & 0.59 \\
\hline & 56DAP & $0.46 \mathrm{Bb}$ & $0.55 \mathrm{ab}$ & $0.56 a$ & $0.57 a$ & $0.54 a b$ & $0.50 \mathrm{ab}$ & $0.57 a$ \\
\hline \multirow[t]{3}{*}{ Soil C/N } & Initial & 11.43 & 11.43 & 11.43B & $11.43 \mathrm{C}$ & $11.43 \mathrm{~A}$ & 11.43B & 11.43B \\
\hline & 28DAI & $11.69 \mathrm{bc}$ & $11.54 \mathrm{c}$ & $9.41 \mathrm{Ce}$ & $11.92 \mathrm{Aa}$ & $10.36 \mathrm{Bd}$ & 11.73Aab & 11.72Aab \\
\hline & 56DAP & $11.61 b$ & $11.43 b$ & 11.79Aa & 11.72Ba & $11.48 \mathrm{Ab}$ & $11.11 C c$ & 11.38Bb \\
\hline \multirow{3}{*}{$\begin{array}{l}\mathrm{NH}_{4}^{+} \\
\left(\mathrm{mg} \mathrm{kg}^{-1}\right)\end{array}$} & Initial & $12.35 \mathrm{~A}$ & $12.35 \mathrm{~A}$ & $12.35 \mathrm{~A}$ & $12.35 \mathrm{~A}$ & $12.35 \mathrm{~A}$ & $12.35 \mathrm{~A}$ & $12.35 \mathrm{~A}$ \\
\hline & 28DAI & 8.10Be & 10.62Bab & 10.90Ba & $9.78 \mathrm{Bbcd}$ & $9.15 \mathrm{Bcd}$ & $9.03 \mathrm{Bd}$ & $9.95 \mathrm{Bbc}$ \\
\hline & 56DAP & $7.42 B c$ & 11.47ABa & 10.55Bab & $10.98 \mathrm{ABab}$ & $8.58 \mathrm{Bbc}$ & 10.81ABab & 9.67Bab \\
\hline \multirow{3}{*}{$\begin{array}{l}\mathrm{NO}_{3}^{-} \\
\left(\mathrm{mg} \mathrm{kg}^{-1}\right)\end{array}$} & Initial & $0.31 B$ & $0.31 B$ & $0.31 B$ & $0.31 \mathrm{~B}$ & $0.31 B$ & $0.31 \mathrm{~B}$ & $0.31 C$ \\
\hline & 28DAI & $0.20 \mathrm{Bb}$ & $0.22 \mathrm{Bb}$ & $0.34 \mathrm{Bb}$ & $0.30 \mathrm{Bb}$ & $0.28 \mathrm{Bb}$ & $0.32 \mathrm{Bb}$ & 0.39Ba \\
\hline & 56DAP & $1.70 A b$ & $2.66 A a$ & $1.90 \mathrm{Ab}$ & $2.00 \mathrm{Ab}$ & $2.86 A a$ & $1.94 \mathrm{Ab}$ & $1.87 \mathrm{Ab}$ \\
\hline \multirow{3}{*}{$\begin{array}{l}\text { Available P } \\
\left(\mathrm{mg} \mathrm{kg}^{-1}\right)\end{array}$} & Initial & $4.82 \mathrm{~B}$ & $4.82 \mathrm{~B}$ & $4.82 \mathrm{~B}$ & $4.82 \mathrm{~B}$ & $4.82 \mathrm{~B}$ & $4.82 \mathrm{C}$ & $4.82 \mathrm{AB}$ \\
\hline & 28DAI & $4.51 \mathrm{Bd}$ & 5.92ABa & 4.93Bbcd & 4.80Bbcd & 5.26Babc & 5.35Bab & $4.61 \mathrm{Bcd}$ \\
\hline & 56DAP & $5.65 \mathrm{Abc}$ & $6.37 \mathrm{Aa}$ & $5.41 \mathrm{Ac}$ & $5.60 \mathrm{Abc}$ & $6.13 \mathrm{Aab}$ & 6.14Aab & $5.32 A c$ \\
\hline Extractable & Initial & $31.63 \mathrm{~A}$ & 31.63B & $31.63 \mathrm{~A}$ & 31.63B & $31.63 \mathrm{AB}$ & 31.63B & 31.63B \\
\hline \multirow[t]{2}{*}{$\mathrm{K}\left(\mathrm{mg} \mathrm{kg}^{-1}\right)$} & 28DAl & 28.79ABd & $65.55 \mathrm{Aa}$ & 36.29Acd & 53.66Aab & $50.32 \mathrm{Ab}$ & 66.67Aa & $48.29 A b c$ \\
\hline & 56DAP & $22.09 \mathrm{Bbc}$ & 26.25Bab & $19.26 \mathrm{Bc}$ & $28.45 \mathrm{Ba}$ & $20.60 \mathrm{Bc}$ & $22.94 \mathrm{Bbc}$ & $20.92 C c$ \\
\hline Extractable & Initial & 57.78B & 57.78B & 57.78B & 57.78B & 57.78B & 57.78B & $57.78 \mathrm{C}$ \\
\hline \multirow[t]{2}{*}{$\mathrm{Ca}\left(\mathrm{mg} \mathrm{kg}^{-1}\right)$} & 28DAl & $68.65 \mathrm{ABd}$ & $92.29 A c$ & $116.93 \mathrm{Aa}$ & 80.73Acd & $109.21 \mathrm{Aab}$ & $90.6 A c$ & $95.61 \mathrm{Bbc}$ \\
\hline & 56DAP & 78.68Ae & 98.64Acd & $128.96 \mathrm{Aa}$ & 86.88Ade & $108.94 \mathrm{Ac}$ & $104.99 A C$ & 121.29Aab \\
\hline Extractable & Initial & $8.68 \mathrm{~B}$ & $8.68 \mathrm{~B}$ & $8.68 C$ & $8.68 \mathrm{~B}$ & $8.68 \mathrm{C}$ & $8.68 \mathrm{~B}$ & $8.68 \mathrm{~B}$ \\
\hline \multirow[t]{2}{*}{$\mathrm{Mg}\left(\mathrm{mg} \mathrm{kg}^{-1}\right)$} & 28DAI & $12.54 \mathrm{Ac}$ & $17.90 \mathrm{Ab}$ & $22.88 \mathrm{Aa}$ & 14.17Ac & 21.07Aa & $17.56 \mathrm{Ab}$ & $18.43 \mathrm{Ab}$ \\
\hline & 56DAP & $8.98 \mathrm{Bd}$ & $16.16 \mathrm{Ab}$ & $20.26 \mathrm{Ba}$ & $12.83 \mathrm{AC}$ & $16.29 \mathrm{Bb}$ & 14.13AC & $16.42 \mathrm{Ab}$ \\
\hline EC & Initial & $0.05 \mathrm{~A}$ & 0.05 & $0.05 \mathrm{~A}$ & 0.05 & $0.05 A$ & $0.05 A$ & 0.05 \\
\hline \multirow[t]{2}{*}{$\left(\mathrm{dS} \mathrm{m} \mathrm{m}^{-1}\right)$} & 28DAI & $0.04 \mathrm{ABabc}$ & $0.05 a$ & $0.04 \mathrm{Bc}$ & $0.04 a b c$ & $0.05 A a$ & $0.05 \mathrm{Aab}$ & $0.04 b c$ \\
\hline & 56DAP & $0.03 \mathrm{Bc}$ & $0.04 a b c$ & $0.05 \mathrm{Bab}$ & $0.05 a$ & $0.04 \mathrm{Bbc}$ & $0.04 \mathrm{Bbc}$ & $0.04 a b c$ \\
\hline CEC & Initial & 2.51 & 2.51 & 2.51 & 2.51 & 2.51 & 2.51 & 2.51 \\
\hline \multirow[t]{2}{*}{$\left(\mathrm{cmol} \mathrm{kg}^{-1}\right)$} & 28DAI & $2.38 \mathrm{~b}$ & $2.48 a b$ & 2.61ab & $2.78 a$ & $2.73 a$ & $2.63 a b$ & $2.62 \mathrm{ab}$ \\
\hline & 56DAP & 2.3 & 2.28 & 2.28 & 2.28 & 2.55 & 2.4 & 2.57 \\
\hline
\end{tabular}

$\mathrm{CT}$ : untreated control, GN: groundnut, TM: tamarind, RS: rice straw, GN+TM: groundnut + tamarind, GN+RS: groundnut + rice straw, TM+RS: tamarind + rice straw

Means in the same row (period) followed by the same upper-case letter(s) are not significantly different at 0.05 probability level by LSD. 
the soil using $20 \mathrm{ml}$ of $1 \mathrm{~N}$ sodium hydroxide as a trapping agent for 24 hours, and titration was carried out to determine unreacted sodium hydroxide using $1 \mathrm{~N}$ hydrochloric acid with phenolphthalein as an indicator. Titration was terminated at the ending point as indicated by pink color. The value was used for calculation of evolved carbon dioxide as the equation below ${ }^{25,26}$ : $\mathrm{mg}$ of $\mathrm{C}$ or $\mathrm{CO}_{2}=(\mathrm{B}-\mathrm{V}) \mathrm{NE}$

where, $B$ is titration volume $(\mathrm{ml})$ of hydrochloric acid in the blank, $\mathrm{V}$ is titration volume (ml) of hydrochloric acid in the treatment with soil, $\mathrm{N}$ is the normality of the acid, and $\mathrm{E}$ is equivalent weight which is 22 for $\mathrm{CO}_{2}$.

Enzyme activity including invertase (EC 3.2.1.26) was measured as described by Schinner and von Mersi cited in Alef and Nannipieri using 50 $\mathrm{mM}$ sucrose as substrate with $2 \mathrm{M}$ acetate buffer (pH 5.5). ${ }^{27,28}$ Activity of invertase was expressed as $\mathrm{mg}$ glucose equivalent (GE) g-1 soil DW $3 \mathrm{~h}^{-1}$. Protease (EC 3.4.2.21-24) activity was measured as described by Ladd and Butler using casein as substrate with $0.05 \mathrm{M}$ tris buffer $(\mathrm{pH} 8.1) .{ }^{29}$ Protease activity was expressed as $\mu \mathrm{g}$ tyrosine equivalents (tyr) per $\mathrm{g}^{-1}$ soil DW $2 \mathrm{~h}^{-1}$. Phenoloxidase (EC 1.10.3.1, 2) and peroxidase (EC 1.11.1.7) activities were measured as described by Hendel et al. using $5 \mathrm{mML}$-3,4-dihydroxyphenylalanine (L-DOPA) as substrate with $50 \mathrm{mM}$ acetate buffer. ${ }^{30}$ For peroxidase activity, $0.3 \%(\mathrm{v} / \mathrm{v})$ hydrogen peroxide $\left(\mathrm{H}_{2} \mathrm{O}_{2}\right)$ was used as electron acceptor. Activity of phenoloxidase was calculated using $1.66 \mu \mathrm{mol}$ as the extinction coefficient for L-DOPA. Similar to phenoloxidase activity, activity of peroxidase was calculated as the difference in activity between samples treated with and without $\mathrm{H}_{2} \mathrm{O}_{2}$. Activities of phenoloxidase and peroxidase were expressed as $\mu \mathrm{mol} 2$,3-dihydroindole-2-carboxylate (dicq) $\mathrm{g}^{-1}$ soil DW $\mathrm{h}^{-1}$.

Plant height was recorded at 56 DAP. The plants were harvested and roots and shoots were separated. The samples were oven-dried and the dry weights of root and shoots were recorded.

\section{Data analysis}

Data for all parameters under study were analyzed statistically according to a randomized complete block design. Means were separated by least significance difference (LSD) at 0.05 probability level. Pearson's correlation was used for calculation of correlation coefficients among parameters under study. All calculations were accomplished by using SPSS software (SPSS, version 16.0).

\section{RESULTS}

\section{Soil chemical properties}

Soil chemical properties of the initiation of the experiment, after incorporation (28 DAI) and after planting (56 DAP) are presented in Table 3. Soils with organic residues at three periods were significantly different $(p \leq 0.05)$ for soil $\mathrm{pH}$. The soil $\mathrm{pH}$ values increased after incorporation and then the values reduced after planting. In contrast, untreated control at three periods had similar soil $\mathrm{pH}$.

For nutrient contents of the soil, all treatments had different $\mathrm{NH}_{4}{ }^{+}$content at different periods. In general, $\mathrm{NH}_{4}^{+}$content was reduced after incorporation and unchanged after planting. The treatments with organic residues had higher $\mathrm{NH}_{4}{ }^{+}$content than untreated control. Among organic treatments, $\mathrm{GN}$ and TM had the highest $\mathrm{NH}_{4}^{+}$content at $28 \mathrm{DAl}$ and $56 \mathrm{DAP}$, whereas all treatments had similar $\mathrm{NO}_{3}^{-}$and available $\mathrm{P}$ content at initiation stage and 28 DAl, but they increased $\mathrm{NO}_{3}{ }^{-}$and available $\mathrm{P}$ content at 56 DAP. The treatments with organic residues had higher $\mathrm{NO}_{3}^{-}$and available $\mathrm{P}$ content than untreated control. Among organic treatments, GN had the highest soil $\mathrm{pH}$ at $28 \mathrm{DAl}$ and TM, GN+TM, GN+RS, and $\mathrm{TM}+\mathrm{RS}$ had the highest soil $\mathrm{pH}$ at $56 \mathrm{DAP}$.

Moreover, Soils with organic residues at three periods were unchanged for SOM content, whereas untreated control decreased SOM content. The result of soil $\mathrm{C} / \mathrm{N}$ ratio found that $\mathrm{CT}$ and $\mathrm{GN}$ had similar $\mathrm{C} / \mathrm{N}$ ratio at three periods. TM and $\mathrm{GN}+\mathrm{TM}$ reduced $\mathrm{C} / \mathrm{N}$ ratio at $28 \mathrm{DAl}$ and it increased $\mathrm{C} / \mathrm{N}$ ratio at $56 \mathrm{DAP}$, while $\mathrm{RS}, \mathrm{GN}+\mathrm{RS}$, and $\mathrm{TM}+\mathrm{RS}$ increased $\mathrm{C} / \mathrm{N}$ ratio at $28 \mathrm{DAl}$ and it reduced $\mathrm{C} / \mathrm{N}$ ratio at $56 \mathrm{DAP}$.

Among organic treatments, $\mathrm{GN}$ and $\mathrm{GN}+\mathrm{TM}$ had the highest $\mathrm{NO}_{3}^{-}$content at $56 \mathrm{DAP}$, and $\mathrm{GN}$ also had the highest available $P$ content at $28 \mathrm{DAl}$ and 56 DAP. The treatments with organic residues increased extractable $\mathrm{K}$, extractable $\mathrm{Ca}$ and extractable $\mathrm{Mg}$ content at $28 \mathrm{DAI}$ and they reduced these nutrients at 56 DAP except for extractable $\mathrm{Ca}$, which was unchanged at 56 DAP. Untreated control continuously reduced extractable K content, but it had similar extractable 
Ca content across three stages. Among organic treatments, GN and RS had the highest extractable $\mathrm{K}$ content at $28 \mathrm{DAl}$ and $56 \mathrm{DAP}$, whereas TM had the highest extractable $\mathrm{Ca}$ and extractable $\mathrm{Mg}$ content at $28 \mathrm{DAl}$ and 56 DAP.

\section{Soil biological properties}

Soil microbial abundance

The results for bacterial abundance during three periods are presented in Fig. 1 a.
Most organic residue treatments had higher bacterial abundance than untreated control except for GN and RS. GN+RS had the highest bacterial abundance at $28 \mathrm{DAl}$ and 56 DAP, whereas untreated control and most organic treatments applied as a single residual except for RS increased bacterial abundance but the organic treatments applied in combinations reduced bacterial
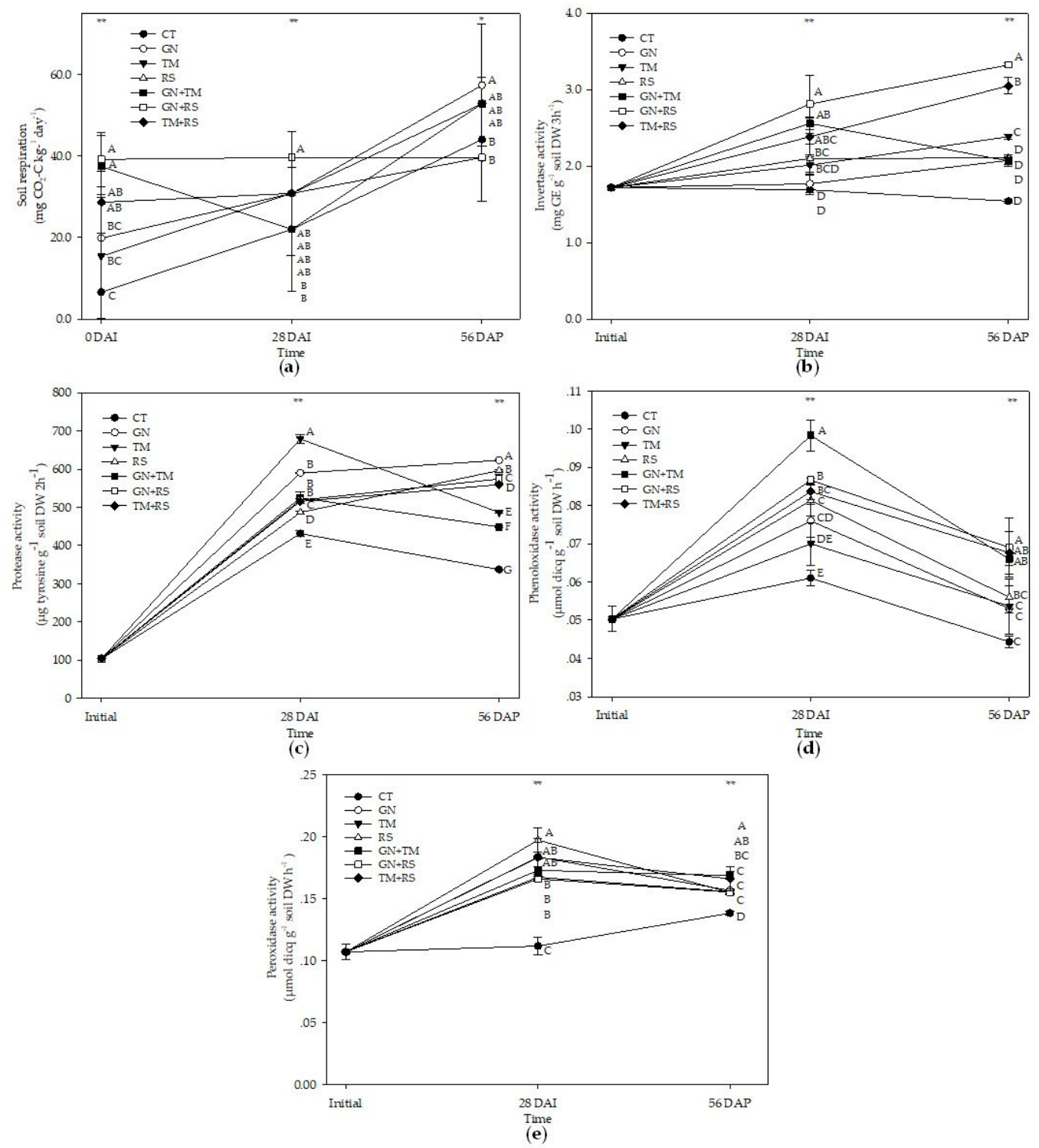

Fig. 2. Soil respiration (a), invertase (b), protease (c), phenoloxidase (d), and peroxidase (e) activity in soil treated with different quality organic (CT: untreated control, GN: groundnut, TM: tamarind, RS: rice straw, GN+TM: groundnut + tamarind, GN+RS: groundnut + rice straw, TM+RS: tamarind + rice straw). ${ }^{*},{ }^{*}$ significantly different at $p<0.05$, and 0.01 , respectively. 
abundance. GN and TM had the highest bacterial abundance at 56 DAP.

The results of archaeal abundance (Fig. 1b) showed that all treatments seemed to increase archaeal abundance at $28 \mathrm{DAI}(p<0.05)$ and the archaeal abundance seemed to be constant at 56 DAP for most treatments except for $\mathrm{GN}+\mathrm{RS}$ reduced archaeal abundance at $56 \operatorname{DAP}(p<0.05)$ and the treatment also had the highest archaeal abundance at $28 \mathrm{DAI}$, whereas RS had the highest archaeal abundance at 56 DAP.

On the contrary, most treatments had constant abundances of fungi across three stages except for GN+TM and TM+RS. GN+TM increased fungal abundance at $28 \mathrm{DAl}$ and it reduced fungal abundance at 56 DAP $(p<0.05)$, whereas TM+RS had a consistent increase in fungal abundance across three stages $(p<0.05)$. GN+TM had the highest fungal abundance at $28 \mathrm{DAl}$ and TM+RS had the highest fungal abundance at 56 DAP (Fig. 1c).

\section{Soil microbial activity}

The results for soil respiration or $\mathrm{CO}_{2}$ emission are presented in Fig. 2a. Most treatments had a constant rate of $\mathrm{CO}_{2}$ release across three stages except for $\mathrm{CT}, \mathrm{GN}$, and GN+TM, which increased rate of $\mathrm{CO}_{2}$ release at $56 \operatorname{DAP}(p<0.05)$. $\mathrm{GN}+\mathrm{RS}$ had the highest rate of $\mathrm{CO}_{2}$ release at 28 DAl, whereas GN had the highest rate of $\mathrm{CO}_{2}$ release at 56 DAP.
The results of enzyme activity are shown in Fig. 2b-e. Most treatments increased invertase activity after incorporation $(p<0.05)$ except for CT and GN, which had constant invertase activity after incorporation. After planting, invertase activity was increased in most treatments except for CT, $\mathrm{RS}$, and GN+TM. GN+RS had the highest invertase activity at $28 \mathrm{DAl}$ and 56 DAP (Fig. 2b).

Protease activity showed for all treatments at 28 DAl was significantly higher than at initial. TM had the highest protease activity at 28 DAI. GN, RS, GN+RS and TM+RS increased protease activity, whereas $\mathrm{CT}, \mathrm{TM}$ and $\mathrm{GN}+\mathrm{TM}$ tended to reduce protease activity $(p<0.05)$, and $\mathrm{GN}$ had the highest protease activity at 56 DAP (Fig. 2c).

The results of phenoloxidase activity (Fig. 2d) showed that all treatments increased phenoloxidase activity at $28 \mathrm{DAl}$ and reduced phenoloxidase activity at $56 \operatorname{DAP}(p<0.05)$. Similar results for most treatments were observed for peroxidase activity (Fig. 2e) except for GN+TM and $T M+R S$, which were constant after planting. $\mathrm{GN}+\mathrm{TM}$ had the highest phenoloxidase activity at $28 \mathrm{DAl}$, and GN+RS had the highest phenoloxidase activity at 56 DAP. RS had the highest peroxidase activity at $28 \mathrm{DAI}$, and GN+TM had the highest peroxidase activity at 56 DAP.

\section{Plant growth}

All organic treatments had higher plant height and dry weigh than CT (Fig. 3a and b). GN

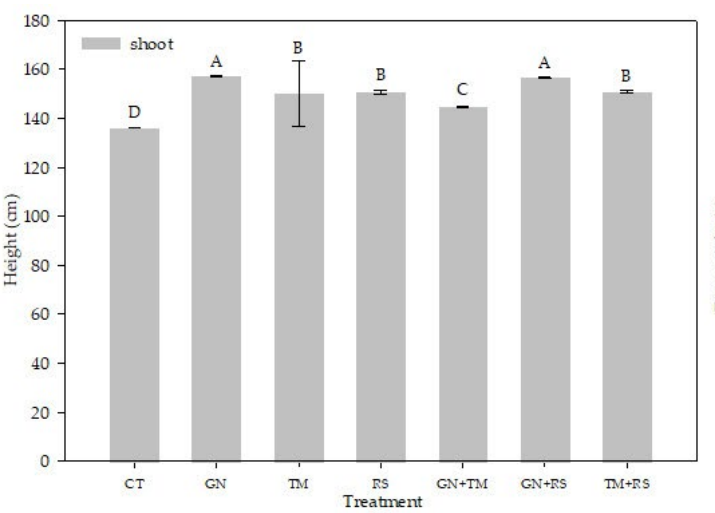

(a)

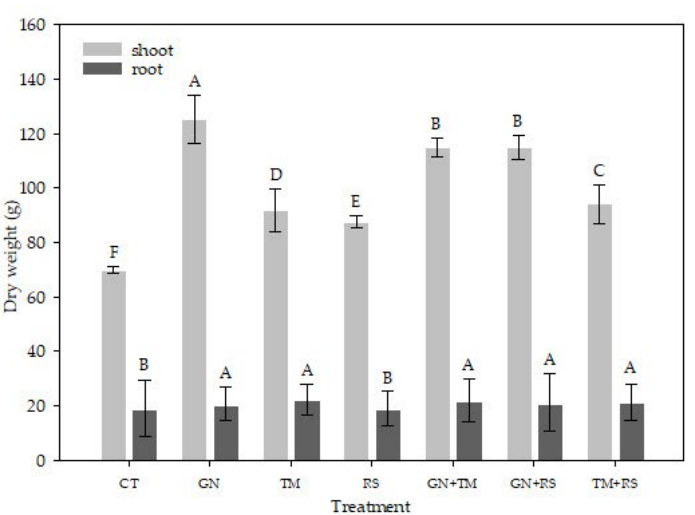

(b)

Fig. 3. Plant height (a), and root dry weight and shoot dry weight (b) of maize at 56 days after planting activity in soil treated with different quality organic (CT: untreated control, GN: groundnut, TM: tamarind, RS: rice straw, GN+TM: groundnut + tamarind, GN+RS: groundnut + rice straw, TM+RS: tamarind + rice straw). Means for the same character with the same letter (lower case) are not significantly different by LSD at 0.05 probability level. 
and GN+RS had the highest plant heights of 157.40 and $157.05 \mathrm{~cm}$, respectively, and $\mathrm{GN}$ also had the highest total dry weight of $145.88 \mathrm{~g}$. CT had the significantly $(p<0.01)$ lowest plant height $(135.68$ $\mathrm{cm}$ ) and total dry weight (88.93 g).

\section{Plant and microbe interactions}

Table 4 showed the relationships among plants, microorganisms and soil at different stages; in the soil initiation of the experiment, a positive and significant correlation between bacteria and fungi was observed. In the soil after incorporation, positive and significant correlations were observed between abundances of bacteria and fungi, abundances of archaea and bacteria, abundances of archaea and fungi, abundance of archaea and extractable Ca content, invertase activity with abundances of archaea, bacteria and fungi, and phenoloxidase activity with abundances of bacteria and fungi, whereas protease activity had negative correlation with $\mathrm{C} / \mathrm{N}$ ratio.

In the soil after planting, abundance of archaea was positively correlated with abundance of bacteria and $\mathrm{C} / \mathrm{N}$ ratio. Invertase and phenoloxidase activity were positively correlated with abundance of fungi but they were negatively correlated with $\mathrm{C} / \mathrm{N}$ ratio, whereas abundance of archaea was positively correlated with protease activity and $\mathrm{C} / \mathrm{N}$ ratio, and soil respiration was positively correlated with $\mathrm{NO}_{3}$ - content.
Table 5 showed the relationship between plant and rhizosphere microorganisms for each treatment which in untreated control, protease had a positively significant correlation with $\mathrm{C} / \mathrm{N}$ ratio at $28 \mathrm{DAl}$. Among organic treatments, bacterial abundance was positively correlated with $\mathrm{NO}_{3}^{-}$content in $\mathrm{GN}$ treatment at $28 \mathrm{DAl}$, and peroxidase activity was positively correlated with $\mathrm{C} / \mathrm{N}$ ratio at 56 DAP. In TM treatment, fungal abundance was positively correlated with $\mathrm{C} / \mathrm{N}$ ratio, and phenoloxidase activity had a positive correlation with extractable Mg at $28 \mathrm{DAl}$, whereas protease activity was positively correlated with SOC at 56 DAP. In RS treatment, the correlation between invertase activity and abundance of fungi was positive and significant and invertase activity was also negatively correlated with abundance of bacteria at $28 \mathrm{DAl}$ and 56 DAP.

In the combination treatment of $\mathrm{GN}+\mathrm{TM}$, protease activity was positively correlated with $\mathrm{N}$ content $\left(\mathrm{NH}_{4}{ }^{+}\right.$and $\left.\mathrm{NO}_{3}{ }^{-}\right)$, abundance of bacteria and abundance of fungi at 28 DAl. In GN+RS treatment, abundance of archaea was negatively correlated with $\mathrm{NH}_{4}{ }^{+}$content at 56 DAP. In TM+RS treatment, abundance of fungi had a positive correlation with extractable Ca content and abundance of bacteria had a positive correlation with $\mathrm{C} / \mathrm{N}$ ratio at 28 DAI, whereas at 56 DAP, invertase was positively correlated with abundances of bacteria and fungi.

Table 4. Pearson's correlation coefficients $(r)$ among biological properties and soil chemical properties evaluated at initial stage of the experiment, 28 days after incorporation (DAI) and 56 days after planting (DAP)

\begin{tabular}{|c|c|c|c|c|c|c|c|c|}
\hline Time & & Arc & Bac & Fungi & Inv & Prot & Phenol & Resp \\
\hline Initial & Fungi & 0.426 & $1.000 * * *$ & 0.000 & 0.402 & 0.305 & 0.323 & 0.442 \\
\hline \multirow[t]{5}{*}{$28 \mathrm{DAI}$} & Fungi & $0.620 * *$ & $1.000 * * *$ & 0.000 & 0.814 & 0.853 & $0.770 * * *$ & 0.246 \\
\hline & $\mathrm{Bac}$ & $0.763 * * *$ & 0.000 & 0.755 & 0.803 & -0.482 & $0.682 *$ & -0.050 \\
\hline & Inv & $0.651^{*}$ & $0.753^{* *}$ & $0.751^{* * *}$ & 0.000 & -0.795 & 0.933 & 0.359 \\
\hline & $\mathrm{C} / \mathrm{N}$ & -0.977 & -0.513 & -0.743 & -0.817 & $-0.742 * * *$ & -0.555 & -0.831 \\
\hline & $\mathrm{Ca}$ & $0.996 * * *$ & 0.845 & 0.811 & 0.766 & -0.568 & 0.642 & 0.054 \\
\hline \multirow[t]{6}{*}{56 DAP } & Bac & $0.770 * *$ & 0.000 & 0.859 & -0.266 & -0.816 & -0.786 & 0.802 \\
\hline & Inv & 0.027 & -0.266 & $0.855^{* *}$ & 0.000 & -0.341 & 0.500 & -0.757 \\
\hline & Phenol & -0.851 & -0.844 & $0.642^{*}$ & 0.501 & 0.642 & 0.000 & -0.189 \\
\hline & Prot & $0.702^{*}$ & -0.813 & -0.841 & -0.314 & 0.000 & 0.645 & -0.817 \\
\hline & $\mathrm{C} / \mathrm{N}$ & $0.475 *$ & 0.831 & 0.818 & $-0.577^{* *}$ & -0.709 & $-0.488^{*}$ & 0.587 \\
\hline & $\mathrm{NO}_{3}^{-}$ & 0.103 & -0.129 & -0.485 & 0.833 & -0.411 & 0.434 & $0.824 * * *$ \\
\hline
\end{tabular}

Arc: archaeal abundance, Bac: bacterial abundance, Fungi: fungal abundance, Resp: soil respiration, Inv: invertase activity, Prot: protease activity, $\mathrm{C} / \mathrm{N}$ : carbon/nitrogen ratio, NO3-: nitrate ion and Ca: extractable calcium $*, * *, * * *$ significant at $0.05,0.01$ and 0.001 probability levels, respectively. 
Table 5. Pearson's correlation coefficients $(r)$ between biological properties and soil chemical properties for each treatment evaluated at initial stage of the experiment, 28 days after incorporation (DAI) and 56 days after planting (DAP)

\begin{tabular}{|c|c|c|c|c|c|c|c|c|}
\hline Treatment & Time & & Arc & Bac & Fungi & Prot & Phenol & Perox \\
\hline \multirow[t]{2}{*}{ CT } & $28 \mathrm{DAI}$ & $\mathrm{C} / \mathrm{N}$ & $-0.999 *$ & -0.513 & -0.743 & 0.999* & -0.555 & 0.781 \\
\hline & 56 DAP & SOM & 0.816 & 0.825 & 0.616 & $-0.999 *$ & -0.656 & 0.331 \\
\hline \multirow[t]{2}{*}{ GN } & $28 \mathrm{DAI}$ & $\mathrm{NO}_{3}^{-}$ & 0.821 & $0.998 *$ & 0.761 & -0.557 & -0.817 & -0.096 \\
\hline & 56 DAP & $\mathrm{C} / \mathrm{N}^{3}$ & -0.762 & -0.821 & -0.118 & -0.843 & 0.253 & $0.997^{*}$ \\
\hline \multirow[t]{2}{*}{ TM } & $28 \mathrm{DAI}$ & $\mathrm{Mg}$ & 0.753 & 0.092 & -0.858 & 0.396 & $-0.999 *$ & -0.733 \\
\hline & & $\mathrm{C} / \mathrm{N}$ & -0.531 & -0.384 & 0.999* & -0.651 & 0.775 & 0.762 \\
\hline \multirow[t]{2}{*}{ RS } & $28 \mathrm{DAl}$ & Inv & -0.328 & $-0.999 *$ & 0.998* & -0.500 & 0.707 & 0.502 \\
\hline & 56 DAP & Inv & 0.419 & -0.999* & 0.998* & 0.697 & 0.500 & -0.521 \\
\hline \multirow[t]{4}{*}{$\mathrm{GN}+\mathrm{TM}$} & $28 \mathrm{DAl}$ & $\mathrm{NH}_{4}^{+}$ & 0.841 & 0.788 & 0.735 & 0.999* & 0.739 & -0.622 \\
\hline & & $\mathrm{NO}_{3}^{-}$ & 0.726 & 0.801 & 0.791 & 0.998* & 0.754 & -0.626 \\
\hline & & $\mathrm{Bac}$ & 0.804 & 0.000 & 0.720 & 0.999* & -0.611 & 0.720 \\
\hline & & Fungi & 0.806 & 0.872 & 0.000 & 0.997* & -0.644 & 0.747 \\
\hline $\mathrm{GN}+\mathrm{RS}$ & 56 DAP & $\mathrm{NH}_{4}^{+}$ & $-0.997 *$ & -0.507 & -0.697 & -0.715 & -0.626 & -0.360 \\
\hline \multirow[t]{3}{*}{$\mathrm{TM}+\mathrm{RS}$} & $28 \mathrm{DAl}$ & $\mathrm{Ca}^{4}$ & 0.677 & -0.579 & $1.000 * *$ & 0.480 & 0.833 & -0.053 \\
\hline & & $\mathrm{C} / \mathrm{N}$ & 0.214 & $1.000 * * *$ & -0.569 & 0.442 & -0.465 & -0.785 \\
\hline & 56 DAP & Inv & 0.809 & 0.999* & $1.000 * *$ & -0.815 & -0.857 & -0.822 \\
\hline
\end{tabular}

CT: untreated control, GN: groundnut, TM: tamarind, RS: rice straw, GN+TM: groundnut + tamarind, GN+RS: groundnut + rice straw, TM+RS: tamarind + rice straw, Arc: archaeal abundance, Bac: bacterial abundance, Fungi: fungal abundance, Inv: invertase activity, Prot: protease activity, Phenol: phenoloxidase activity, Perox: peroxidase activity, $\mathrm{C} / \mathrm{N}$ : carbon/nitrogen ratio, $\mathrm{NO}_{3}{ }^{-}$: nitrate ion, $\mathrm{NH}_{4}^{+}$: ammonium ion, $\mathrm{Ca}$ : extractable calcium, Mg: extractable magnesium and SOM: soil organic matter $*, * *, * * *$ significant at $0.05,0.01$ and 0.001 probability levels, respectively.

\section{DISCUSSION}

Effects of organic materials on soil properties, crop growth and the interaction between crop and populations of microorganisms in root zone

\section{Soil chemical properties}

Application of organic materials for 28 days could improve soil chemical properties as the organic treatments increased soil $\mathrm{pH}, \mathrm{NO}_{3}$, available $\mathrm{P}$, extractable $\mathrm{K}$ and extractable $\mathrm{Mg}$ compared to untreated control. GN and TM were the best choices for improving soil chemical properties compared to other organic treatments.

TM had intermediate nitrogen and recalcitrant carbon compounds and it also had high other nutrients including $\mathrm{Ca}, \mathrm{Mg}$. Therefore, TM had the highest $\mathrm{NH}_{4}{ }^{+}$, extractable $\mathrm{Ca}$ and extractable $\mathrm{Mg}$ in the soil. Furthermore, treatment combination of GN+TM, which had high and intermediate quality, respectively, had high extractable $\mathrm{Ca}$ and the treatment also caused high $\mathrm{NO}_{3}{ }^{-}$and available $\mathrm{P}$ during incorporation period. The increase in $\mathrm{pH}$ values after incorporation of the soil samples would be possibly due to the enzyme activity to decompose organic residue of soil microorganisms, which were induced by the organic residue. Decomposing process released both anions and cations. However, anions were released greater than cations because plant tissues consisted of higher anions. Therefore, $\mathrm{pH}$ values increased at the early stages (2-3 weeks) of decomposing process. Soil microorganisms also contributed to the increase in $\mathrm{pH}$ values by changing organic into inorganic forms of $\mathrm{NH}_{4}^{+}$ (mineralization). ${ }^{31}$ According to Yan et al., the increase in $\mathrm{pH}$ values was caused by decomposition of organic anions and organic nitrogen. The reduction in $\mathrm{pH}$ values after planting was due to nutrient uptake by plant. ${ }^{32}$ Roots also released $\mathrm{H}^{+}$ into the soil to adjust pH balance in the cells. ${ }^{33,34}$. $\mathrm{N}$ uptake is also the cause of high soil $\mathrm{pH}$ because roots release $\mathrm{OH}^{-}$or $\mathrm{HCO}_{3}$. In contrast, if plant take up $\mathrm{N}$ in the form of $\mathrm{NH}_{4}^{+}$, roots releases $\mathrm{H}^{+}$and $\mathrm{pH}$ value in root zone is reduced. ${ }^{35,38}$ Furthermore, change in $\mathrm{NH}_{4}{ }_{4}^{+}$into $\mathrm{NO}_{3}{ }_{3}^{-}$is another factor for low soil $\mathrm{pH}^{39}$ that in accordance with this study, soil $\mathrm{NH}_{4}^{+}$tended to reduce but soil $\mathrm{NO}_{3}^{-}$tended to increase after planting. 
Our results agreed with those in previous studies. Chen et al. also pointed out that phosphate solubilizing bacteria released organic acids in root zone and therefore increased acidity. ${ }^{40}$ Phosphate solubilizing bacteria are generally found in the rhizosphere, ${ }^{41,42}$ and this might the factor for available $\mathrm{P}$ increase after planting. Moreover, the increase in available $\mathrm{P}$ after planting would also be due to the release of organic acids that helped increase availability of $\mathrm{P}$ and prevent $\mathrm{P}$ absorption in soil particles or cations complexing in the soil. ${ }^{43}$ Many crop species release organic acids from root under phosphate deficiency. ${ }^{44-46}$ Additionally, maize requires high $P$ nutrient during early growth stages $^{47,48}$ that increased available $P$ content in the soil after planting.

In this study, TM had the highest Ca and $\mathrm{Mg}$, resulting in high extractable $\mathrm{Ca}$ and extractable $\mathrm{Mg}$ in the soil. The results agreed with the report previously by Xayavong. ${ }^{5}$

Soil biological properties and interactions between plant and microbe in rhizospheric soil treated with different quality organic residues

In this study, application of organic residue improved soil biological properties as indicated by higher abundance of bacteria, fungi and archaea, soil respiration, invertase activity, protease activity, phenoloxidase activity and peroxidase activity compared to untreated control.

There were dynamic changes in microbial abundances and enzyme activity throughout the course of experiment because the organic residue provides a source of nutrients and $\mathrm{C}$ to the soil, which were necessary for abundance buildup of microorganisms and increase in enzyme activity. ${ }^{49-51}$ The plant also continuously released root exudates that provided food and energy to the soil microorganisms. This was also an important factor enhancing the increase in microbial abundances and enzyme activity. ${ }^{52,53}$ Plant age is also an important factor affecting soil microorganisms. At early growth stages, soil microorganisms exploited food and energy from root exudates rather than dead tissues. At late growth stages, plant tissues and outer root layer are indicators for types, quantity and enzyme activity of soil microorganisms. ${ }^{54-56}$ Therefore, plant age that determines quantity of root exudates, dead tissues and root outer skin is also an important factor affecting the change in abundances of microorganisms at different ages.

The results for microbial abundance, enzyme activity and the relationships between microorganisms and properties of the soil treated with different quality organic residues at different stages (at initiation of the experiment, after incorporation and after planting) indicated that application of organic residue increased abundances of bacteria and archaea that play a role in decomposition of organic residue. Organic residue rich in $\mathrm{Ca}$ enhanced abundance of archaea. In addition, bacteria, fungi and archaea played a role in producing invertase, an enzyme that digests labile organic $\mathrm{C}$ compounds. Bacteria and fungi also produced phenoloxidase that decomposed the recalcitrant organic C compounds. Root exudates during crop growth period affected soil microorganisms. As a result, the abundances of bacteria, fungi and archaea were rather constant and these microorganisms played a role in $\mathrm{NO}_{3}$ increase from the transformation of $\mathrm{NH}_{4}^{+}$to $\mathrm{NO}_{3}$. Archaea also played a role in protease production. In this study, fungi were also important for producing invertase and phenoloxidase in the rhizosphere similar to that after incorporation period. Organic treatments with high $\mathrm{N}$ and intermediate $\mathrm{N}$ (GN, TM) had the highest abundances of bacteria, fungi, and archaea.

For microorganism activity, the soils with organic residues increased soil respiration or released higher $\mathrm{CO}_{2}$ after planting, indicating that root exudates could promote microorganism activity. The treatment with high N (GN) and the treatment with high labile $\mathrm{C}$ (RS) had the highest $\mathrm{CO}_{2}$ release. In previous study, the soil with high labile $\mathrm{C}$ and low recalcitrant $\mathrm{C}$ such as rice straw had higher release of $\mathrm{CO}_{2}$ than the soil with high recalcitrant $\mathrm{C}$ and low labile $\mathrm{C}{ }^{4}$

The results in this study also indicated that application of organic residue increased enzyme activity to decompose organic residue into usable forms. At early stages of decomposing process, the activity of the enzymes such as phenoloxidase and peroxidase that are related to decomposing the recalcitrant $C$ increased after incorporation. GN+TM had the highest phenoloxidase activity, whereas RS had the highest peroxidase activity. According to Kamolmanit, phenoloxidase activity 
was high at early stages of decomposing process for organic residues with intermediate to high $\mathrm{N}$ such as groundnut and tamarind. ${ }^{57}$ DeAngelis et al. also reported that oxidative activities of phenoloxidase and peroxidase were responsible for decomposing the organic residue at early phases of the process and hydrolytic activities of hydrolytic enzymes were responsible for decomposing the organic residue at late phases. ${ }^{58}$ The latter enzyme groups are related to decomposing protein, lipids, nucleic acids, carbohydrate and phosphate ester. The increase in available form of $\mathrm{N}$ during decomposing process of organic residue could stimulate phenoloxidase activity. ${ }^{59}$

The results for chemical and biological properties of the untreated soil revealed that changes in most soil properties were in similar patterns of those treated with organic residues. The results indicated that root exudates and plant debris might be an important source of $\mathrm{C}$ and energy for soil microorganisms for growth and activities. $^{60-63}$

The results for the relationships between microorganisms and soil properties after incorporation and after planting indicated that protease activity was positively associated with $\mathrm{C} / \mathrm{N}$ ratio in untreated soil, and the correlation coefficients were not significant in organic soils. Similar to this study, Geisseler and Horwath found that protease activity was related to the $C$ to $\mathrm{N}$ ratio of the amendments. Microorganisms have developed multiple strategies to respond to $\mathrm{C}$ and $\mathrm{N}$ limitations, one of which is the increased synthesis of extracellular protease. Microorganisms regulate protease synthesis depending on their needs for $\mathrm{C}$ and $\mathrm{N} .{ }^{64}$

The organic residues used in this study were different in quality as indicated by chemical compositions of the residues such as $\mathrm{C}$ and $\mathrm{N}$ compositions. $\mathrm{GN}$ had high $\mathrm{N}$ and low recalcitrant C. TM had intermediate $\mathrm{N}$ and recalcitrant $\mathrm{C}$. RS had had high labile $C$ and low N. Application of organic residues for both single residues and in combinations with other residues had a significant effect on microbial abundances such as bacteria, fungi, and archaea. The microorganisms produced enzymes including invertase, phenoloxidase and peroxidase responsible for decomposing organic residues. Invertase decomposes labile
C. Phenoloxidase and peroxidase decomposes recalcitrant $\mathrm{C}$ and protease decomposes protein.

The relationships between organic residues and soil microorganisms were different among organic treatments. Bacterial abundance was positively correlated with soil $\mathrm{NO}_{3}{ }^{-}$after incorporation and after planting, indicating that high $\mathrm{N}$ compounds in $\mathrm{GN}$ increased bacterial abundance and soil $\mathrm{NO}_{3}{ }^{-}$. The increase in bacterial abundance would be possibly affected by root exudates and plant debris that provided $\mathrm{N}$ to the bacteria. In TM treatment, phenoloxidase activity was negatively correlated with extractable $\mathrm{Mg}$ after incorporation and after planting, indicating that $\mathrm{Mg}$ in $\mathrm{TM}$ had a significant effect on phenoloxidase. According to Delkash-Roudsari et al., Mg inhibited phenoloxidase production in Ephestia kuehniella. ${ }^{65}$ In RS treatment, invertase activity was positively correlated with fungal abundance and negatively correlated with bacterial abundance after incorporation and after planting, indicating that high $\mathrm{CL}$ in RS promoted invertase activity by the fungi. In the treatments with the combination of two organic residues with different quality such as $\mathrm{GN}+\mathrm{TM}$, soil $\mathrm{NH}_{4}{ }^{+}$and $\mathrm{NO}_{3}^{-}$ were positively correlated with the abundances of bacteria and fungi, and abundances of bacteria and fungi were positively correlated with protease activity after incorporation, indicating that $\mathrm{GN}$ and TM with high $\mathrm{N}$ increased abundances of bacteria and fungi. These microorganisms played a role in protease production to decompose protein in $\mathrm{GN}$ and TM.

In GN+RS treatment, archaeal abundance was positively correlated with soil $\mathrm{NH} 4+$, indicating that organic residue with high $\mathrm{N}$ (high quality) in combination with organic residue with low $\mathrm{N}$ (low quality) increase abundance of archaea, which is an autotroph responsible for transforming inorganic $\mathrm{N}$ and reducing $\mathrm{NH}_{4}^{+}$. The results were in agreement with those in previous studies. Muema et al. found that intermediate quality organic residue (Calliandra calothyrsus) caused the lowest abundance of ammonia-oxidizing archaea compared to high quality organic residue (Tithonia diversifolia) and low quality organic residue (maize stover). ${ }^{66}$ In the combination treatment of TM+RS, abundance of fungi was positively correlated with extractable $\mathrm{Ca}$ after incorporation, indicating that $\mathrm{Ca}$ in TM and RS increased abundance of fungi. 
The results indicated that application of organic residue could improve chemical and biological properties of the soil as the organic treatments had better growth of maize than untreated control, and GN had the highest plant height and total dry weight of $157.40 \mathrm{~cm}$ and $145.88 \mathrm{~g}$, respectively. The highest growth of maize in $\mathrm{GN}$ treatment was due to high $\mathrm{N}$, intermediate $\mathrm{K}, \mathrm{Ca}$ and $\mathrm{Mg}$, low $\mathrm{C} / \mathrm{N}$ ratio and low recalcitrant $\mathrm{C}$ compounds such as polyphenols and lignin. Therefore, these properties of GN promote the increase in microorganism abundances and enzyme activity related to decomposition of organic residue. Therefore, growth of maize was highest in this treatment.

\section{CONCLUSIONS}

Our empirical outcomes showed that different quality organic residues improved chemical and biological soil properties in different ways. Organic residues amendment increased the abundances of microorganisms (i.e., bacteria, fungi and archaea), stimulated enzyme activities (i.e., increased invertase activity, protease activity, phenoloxidase activity and peroxidase activity), and increased soil pH and nutrients (i.e., nitrogen, available phosphorus, extractable minerals of potassium, calcium, and magnesium). As a result of utilizing organic residues for planting maize crops, it increased plant height and dry matter of maize compared to untreated control. Applying high (groundnut) and intermediate (tamarind) quality as both single and mixed residue additions resulted in more significant soil microbial properties and nutrients than using organic residues with low quality (rice straw). Accordingly, they increased microbial abundances, produced incredible enzymes related to the decomposition of organic residue, and enhanced soil nutrients and plant growth.

Furthermore, the recent results indicated that the chemical compositions of the organic residues amendment regulated soil microbial abundance and enzyme activity both after incorporation and after planting. Specifically, the relationship between nitrate and bacterial abundance was positively found in groundnut. Similarly, a relationship between soil nitrogen (nitrate and ammonium) and protease activity was positively found in groundnut + tamarind.
On the other hand, negative relationship between magnesium and phenoloxidase activity was found in tamarind. In addition, compared with the soil before planting, the increase of rhizosphere bacterial and archaeal abundance and microbial activities like soil respiration, invertase, protease and peroxidase activity were observed during vegetative growth. Interestingly, the application of organic residues could maintain a constant level of soil organic matter after incorporation and planting, whereas soil organic matter seemed to reduce in the untreated control.

\section{ACKNOWLEDGMENTS}

We would like to thank the Department of Soil Science and Environment, Faculty of Agriculture, Khon Kaen University for facilitating laboratory throughout the study.

\section{CONFLICT OF INTEREST}

The authors declare that there is no conflict of interest.

\section{AUTHORS' CONTRIBUTION}

PL was principal researcher. PL designed the experiments. SS performed the experiments. SS, BK and PL analyzed the data. PL and SS wrote and reviewed the manuscript. All authors read and approved the manuscript.

\section{FUNDING}

This research was supported by research grant from Khon Kaen University; project number 6200005, Research and Graduate Studies and Soil Organic Matter Management Research Group, Khon Kaen University.

\section{DATA AVAILABILITY}

All datasets generated or analyzed during this study are included in the manuscript.

\section{ETHICS STATEMENT}

This article does not contain any studies with human participants or animals performed by any of the authors.

\section{REFERENCES}

1. Kumar K, Goh KM. Biological nitrogen fixation, accumulation of soil nitrogen and nitrogen balance for white clover (Trifolium repens L.) and field 
pea (Pisum sativum L.) grown for seed. Field Crop Res. 2000;68(1):49-59. doi: 10.1016/S03784290(00)00109-X

2. Singh $Y$, Singh B, Timsina J. Crop residue management for nutrient cycling and improving soil productivity in rice-based cropping systems in the tropics. Adv Agron. 2005;85:269-407. doi: 10.1016/\$0065-2113(04)850065

3. Blanchart E, Albrecht A, Bernoux M, et al. Organic matter and biofunctioning in tropical sandy soils and implications for its management. In 1st International Symposium on the Management of tropical Sandy Soils for Sustainable Agriculture "a holistic approach for sustainable development of problem soils in the tropics". Khon Kaen, Thailand, 2005:224-241.

4. Puttaso A, Vityakon P, Saenjan P, Trelo-ges V, Cardisch G. Relationship between residue quality, decomposition patterns, and soil organic matter accumulation in a tropical sandy soil after 13 years. Nutr Cycl Agroecosys. 2011;89:159-174. doi: 10.1007/s10705-010-9385-1

5. Xayavong S. Change in soil chemical properties affect plant response under 20-year application of contrasting quality organic residues with and without chemical fertilizers. M.S. Thesis, Khon Kaen University, Khon Kaen. 2017. https://opac.kku.ac.th/Catalog/ Bibltem.aspx?BibID=b00422307

6. Hoorman JJ, Islam R. Understanding soil microbes and nutrient recycling. Agric Nat Resour. 2010;1-5.

7. Jacoby $R$, Peukert $M$, Succurro A, Koprivova A, Kopriva $S$. The role of soil microorganisms in plant mineral nutrition-current knowledge and future directions. Front Plant Sci. 2017;8:1617. doi: 10.3389/ fpls.2017.01617

8. Pereg L, McMillan M. Scoping the potential uses of beneficial microorganisms for increasing productivity in cotton cropping systems. Soil Biol Biochem. 2015;80:349-358. doi: 10.1016/j.soilbio.2014.10.020

9. Khatoon $\mathrm{H}$, Solanki $\mathrm{P}$, Narayan $\mathrm{M}$, Tewari L, Rai J. Role of microbes in organic carbon decomposition and maintenance of soil ecosystem. Int J Chem Stud. 2017;5(6):1648-1656.

10. Kamolmanit B. Soil fungal communities and microbial functions affecting soil organic matter changes in a sandy soil treated with biochemically contrasting organic inputs. Ph.D. Thesis, Khon Kaen University, Khon Kaen. 2014.

11. Partey ST, Preziosi RF, Robson GD. Maize residue interaction with high quality organic materials: effects on decomposition and nutrient release dynamics. Agric Res. 2013;2(1):58-67. doi: 10.1007/s40003-0130051-0

12. Palm CA, Gachengo CN, Delve RJ, Cardisch G, Giller KE. Organic inputs for soil fertility management in tropical agroecosystems: application of an organic resource database. Agric Ecosyst Environ. 2001;83:27-42. doi: 10.1016/S0167-8809(00)00267-X

13. Kaewpradit W, Toomsan B, Vityakon P, et al. Regulating mineral $\mathrm{N}$ release and greenhouse gas emissions by mixing groundnut residues and rice straw under field conditions. Eur J Soil Sci. 2008;59(4):640-652. doi: 10.1111/j.1365-2389.2008.01021.x

14. Walkley A, Black CA. Organic carbon. Methods of soil analysis. American Society of Agronomy, Madison. 1965;37:1372-1375.

15. Bremner JM. Total Nitrogen. Methods of Soil Analysis: Part 2 Chemical and Microbiological Properties. J Am Soc Agron. 1965;1049-1178.

16. Beathgen WE, Alley MM. Optimizing soil and fertilizer nitrogen use by intersively managed winter wheat: critical level and optimums rates of nitrogen fertilizer. Agron. 1989;81(1):120-125. doi: 10.2134/agronj1989 $.00021962008100010028 x$

17. Cataldo DA, Maroon M, Schrader LE, Youngs VL. Rapid colorimetric determination of nitrate in plant tissue by nitration of salicylic acid. Commun Soil Sci Plant. 1975;6(1):71-80. doi: 10.1080/00103627509366547

18. Bray RH, Kurtz LT. Determination of total, organic, and available forms of phosphorus in soil. Soil Sci. 1945;59(1):39-45.

19. Isaac RA, Kerber JD. Atomic absorption and flame photometry: Techniques and uses in soil, plant, and water analysis. In Walsh LM (ed.), Instrumental methods for analysis of soils and plant tissue. Soil Science Society of America, Madison. 1971:17-37.

20. Schollenberger $\mathrm{CJ}$, Simon RH. Determination of exchange capacity and exchangeable bases in soil-ammonium acetate method. Soil Science. 1945;59(1):13-24. doi: 10.1097/00010694-19450100000004

21. Lane DJ. 16S/23S rRNA sequencing. In Stackebrandt A, Goodfellow M (eds.), Nucleic acid techniques in bacterial systematics. John Wiley, West Sussex, UK. 1991:115-175.

22. Muyzer G, De Waal EC, Uitterlinden AG. Profiling of complex microbial populations by denaturing gradient gel electrophoresis analysis of polymerase chain reaction-amplified genes coding for $16 \mathrm{~S}$ rRNA. Appl Environ Microbiol. 1993;59(3):695-700. doi: 10.1128/ aem.59.3.695-700.1993

23. Vainio EJ, Hantula J. Direct analysis of wood-inhabiting fungi using denaturing gradient gel electrophoresis of amplified ribosomal DNA. Mycol Res. 2000;104(8):927936. doi: 10.1017/S0953756200002471

24. Lueders T, Friedrich M. Archaeal population dynamics during sequential reduction processes in rice field soil. Appl Environ Microbiol. 2000;66(7):2732-2742. doi: 10.1128/AEM.66.7.2732-2742.2000

25. Anderson JPE. Soil respiration. In Page AL, Miller RH, Keeney DR (eds.), Methods of soil analysis: Part 2 Chemical and microbiological properties, 2nd Ed. American Society of Agronomy and Crop Science Society of America, Madison, Wisconsin, USA. 1982:831-871.

26. Rowell MJ. Colorimetric method for $\mathrm{CO}_{2}$ measurement in soils. Soil Biol Biochem. 1995;27(3):373-375. doi: 10.1016/0038-0717(94)00218-P

27. Schinner F, Von Mersi W. Xylanase-, CM-cellulase-, and invertase activity in soil: an improved method. Soil Biol Biochem. 1990;22(4):511-515. doi: 10.1016/00380717(90)90187-5

28. Alef $\mathrm{K}$, Nannipieri P. B-glucosidase activity. In Alef K, Nannipieri P (eds,), Methods in applied soil microbiology and biochemistry. Academic Press, San Diego, London. 1995 
29. Ladd JN, Butler JHA. Short-term assay of soil proteolytic enzyme activities using proteins and dipeptide derivates as substrates. Soil Biol Biochem. 1972;4(1):19-30. doi: 10.1016/0038-0717(72)90038-7

30. Hendel B, Sinsabaugh RL, Marxsen J. Lignin-degrading enzymes: phenoloxidase and peroxidase. In Graça MAS, Bärlocher F, Gessner MO (eds.), Methods to study litter decomposition: a practical guide. Springer, Dordrecht. 2005:273-277.

31. Xiao K, Yu L, Xu J, Brookes PC. pH, nitrogen mineralization, and $\mathrm{KCl}$-extractable aluminum as affected by initial soil $\mathrm{pH}$ and rate of vetch residue application: results from a laboratory study. J Soils Sediments. 2014;14(9):1513-1525. doi: 10.1007/ s11368-014-0909-1

32. Yan F, Schubert S, Mengel K. Soil pH changes during legume growth and application of plant material. Biol Fertil Soils. 1996;23:236-242. doi: 10.1007/ BF00335950

33. Sas L, Rengel Z, Tang C. Excess cation uptake, and extrusion of protons and organic acid anions by Lupinus albus under phosphorus deficiency. Plant Sci. 2001;160(6):1191-1198. doi: 10.1016/S01689452(01)00373-9

34. Hinsinger P, Plassard C, Tang C, Jaillard B. Origins of root-mediated $\mathrm{pH}$ changes in the rhizosphere and their responses to environmental constraints: a review. Plant Soil. 2003;248(1):43-59. doi: 10.1023/A:1022371130939

35. Smiley RW. Rhizosphere $\mathrm{pH}$ as Influenced by Plants, Soils, and Nitrogen Fertilizers. Soil Sci Soc Am J. 1974;38(5):795-799. doi: 10.2136/ sssaj1974.03615995003800050030x

36. Romheld V. pH changes in the rhizosphere of various crop plants in relation to the supply of plant nutrients. Potash Rev. 1986;12:1-12.

37. Gahoonia TS, Claassen N, Jungk A. Mobilization of phosphate in different soils by ryegrass supplied with ammonium or nitrate. Plant Soil. 1992;140(2):241-248. doi: 10.1007/bf00010600

38. Hinsinger P. Bioavailability of soil inorganic $P$ in the rhizosphere as affected by root-induced chemical changes: a review. Plant Soil. 2001;237(2):173-195. doi: 10.1023/A:1013351617532

39. McCauley A, Jones C, Jacobsen J. Commercial fertilizers and soil amendments. In Nutrient Management Module No 10, Nutrient Management a self-study course from MSU Extension Continuing Education Series. Montana State University. 2009. https://www. certifiedcropadviser.org/files/certifications/certified/ education/self-study/exam-pdfs/40.pdf

40. Chen YP, Rekha PD, Arun AB, Shen FT, Lai W-A, Young CC. Phosphate solubilizing bacteria from subtropical soil and their tricalcium phosphate solubilizing abilities. Appl Soil Ecol. 2006;34(1):33-41. doi: 10.1016/j.apsoil.2005.12.002

41. SkraryFA, Cameron DC. Purification and characterization of a Bacillus licheniformis phosphatase specific ford- $\alpha$-Glycerophosphate. Arch Biochem Biophys. 1998;349(1):27-35. doi: 10.1006/abbi.1997.0433

42. El-Azeem SA, Mehana TA, Shabayek AA. Some plant growth promoting traits of rhizobacteria isolated from Suez Canal region, Egypt. In African Crop Science Conference Proceedings. El-Minia, Egypt. 2007:15171525.

43. Bais HP, Weir TL, Perry LG, Gilroy S, Vivanco JM. The role of root exudates in rhizosphere interactions with plants and other organisms. Annu Rev Plant Biol. 2006;57(1):233-266. doi: 10.1146/annurev. arplant.57.032905.105159

44. Hoffland E, van den Boogaard RIKI, Nelemans JAAP, Findenegg $G$. Biosynthesis and root exudation of citric and malic acids in phosphate-starved rape plants. New Phytol. 1992;122(4):675-680. doi: 10.1111/j.14698137.1992.tb00096.x

45. Zhang FS, Ma J, Cao YP. Phosphorus deficiency enhances root exudation of low-molecular weight organic acids and utilization of sparingly soluble inorganic phosphates by radish (Raghanus satiuvs L.) and rape (Brassica napus L.) plants. Plant Soil. 1997;196(2):261-264. doi: 10.1023/A:1004214410785

46. Wang $\mathrm{Y}$, Lambers $\mathrm{H}$. Root-released organic anions in response to low phosphorus availability: recent progress, challenges and future perspectives. Plant Soil. 2020;447(1-2):135-156. doi: 10.1007/s11104019-03972-8

47. Grant CA, Flaten DN, Tomasiewicz DJ, Sheppard SC. The importance of early season phosphorus nutrition. Can J Plant Sci. 2001;81(2):211-224. doi: 10.4141/p00-093

48. Nadeem M, Mollier A, Morel C, Vives A, Prud'homme $L$, Pellerin S. Relative contribution of seed phosphorus reserves and exogenous phosphorus uptake to maize (Zea mays L.) nutrition during early growth stages. Plant and Soil. 2001;346:231-244. doi: 10.1007/ s11104-011-0814-y

49. Fang $\mathrm{Y}$, Singh BP, Collins D, Li B, Zhu J, Tavakkoli E. Nutrient supply enhanced wheat residue-carbon mineralization, microbial growth, and microbial carbon-use efficiency when residues were supplied at high rate in contrasting soils. Soil Biol Biochem. 2018;126:168-178. doi: 10.1016/j.soilbio.2018.09.003

50. Hok L, De Moraes Sa JC, Reyes MR, et al. Enzymes and $C$ pools as indicators of $C$ build up in short-term conservation agriculture in a savanna ecosystem in Cambodia. Soil Tillage Res. 2018;177:125-133. doi: 10.1016/j.still.2017.11.015

51. Loeppmann S, Breidenbach A, Spielvogel S, Dipold MA, Blagodatskaya E. Organic nutrients induced coupled $\mathrm{C}$-and $\mathrm{P}$-cycling enzyme activities during microbial growth in forest soils. Front For Glob Change. 2020;3:100. doi: 10.3389/ffgc.2020.00100

52. Norton JM, Smith JL, Firestone MK. Carbon flow in the rhizosphere of ponderosa pine seedlings. Soil Biol Biochem. 1990;22(4):449-455. doi: 10.1016/00380717(90)90177-2

53. Norton JM, Firestone MK. Metabolic status of bacteria and fungi in the rhizosphere of ponderosa pine seedlings. Appl Environ Microbiol. 1991;57(4):11611167. doi: 10.1128/aem.57.4.1161-1167.1991

54. Gomes NCM, Fagbola O, Costa R, et al. Dynamics of fungal communities in bulk and maize rhizosphere soil in the tropics. Appl Environ Microbiol. 2003;69(9):37583766. doi: 10.1128/aem.69.9.5737.2003

55. Singh BK, Munro S, Potts JM, Millard P. Influence 
of grass species and soil type on rhizosphere microbial community structure in grassland soils. Appl Soil Ecol. 2007;36(2-3):147-155. doi: 10.1016/j. apsoil.2007.01.004

56. Broeckling CD, Broz AK, Bergelson J, Manter DK, Vivanco JM. Root exudates regulate soil fungal community composition and diversity. Appl Environ Microbiol. 2008;74(3):738-744. doi: 10.1128/aem.02188-07

57. Kamolmanit B, Vityakon P, Kaewpradit W, Cadisch $G$, Rasche F. Soil fungal communities and enzyme activities in a sandy highly weathered tropical soil treated with biochemically contrasting organic inputs. Biol Fertil Soils. 2013;49(7):905-917. doi: 10.1007/ s00374-013-0785-7

58. Deangelis KM, Chivian D, Fortney JL, et al. Changes in microbial dynamics during long-term decomposition in tropical forests. Soil Biol Biochem. 2013;66:60-68. doi: 10.1016/j.soilbio.2013.06.010

59. Bragazza L, Buttler A, Habermacher J, et al. High nitrogen deposition alters the decomposition of bog plant litter and reduces carbon accumulation. Glob Chang Biol. 2012;18(3):1163-1172. doi: 10.1111/j.1365-2486.2011.02585.x

60. Rovira AD. Plant root exudates. Bot Rev. 1969;35:35-57. doi: 10.1007/BF02859887

61. Curl EA, Truelove B. Root exudates. In The rhizosphere,
Advanced Series in Agricultural Sciences. Springer, Berlin, Heidelberg. 1986:55-92.

62. Bakker PAHM, Pieterse CMJ, de Jonge R, Berendsen RL. The soil-borne legacy. Cell. 2018;172(6):1178-1180. doi: 10.1016/j.cell.2018.02.024

63. Yuan J, Zhao J, Wen T, et al. Root exudates drive the soil-borne legacy of aboveground pathogen infection. Microbiome. 2018;6:156. doi: 10.1186/s40168-0180537-x

64. Geisseler D, Horwath WR. Regulation of extracellular protease activity in soil in response to different sources and concentrations of nitrogen and carbon. Soil Biol Biochem. 2008;40(12):3040-3048. doi: 10.1016/j. soilbio.2008.09.001

65. Delkash-RoudsariS, Zibaee A, Bigham Z. Purification and characterization of a phenoloxidase in the hemocytes of Ephestia kuehniella Zeller (Lepidoptera: Pyralidae): effects of insect growth regulators and endogenous inhibitors. J Enzym Inhib Med Chem. 2015;30(4):569574. doi: 10.3109/14756366.2014.954107

66. Muema EK, Cadisch G, Rohl C, Vanlauwe B, Rasche F. Response of ammonia-oxidizing bacteria and archaea to biochemical quality of organic inputs combined with mineral nitrogen fertilizer in an arable soil. Appl Soil Ecol. 2015;95:128-139. doi: 10.1016/j. apsoil.2015.06.019 